\title{
Direct and Indirect Effects of Cash Dividend Policies on Firms' Capital Accumulation in Selected Developed Markets*
}

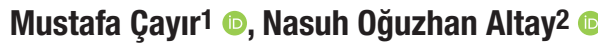

\begin{abstract}
The effects of cash dividend policies on the capital accumulation of non-bank firms operating in The United States (S\&P 500), The United Kingdom (FTSE 100), Japan (Nikkei 225), and France (CAC 40) have been investigated in this study. The dataset used in the study consists of annual observations between 2010 and 2015. Also, the data were retrieved from the Thomson Reuters database. The system in GMM is employed in the econometric estimations in this paper. "Total effect" of cash dividend policies on capital accumulation has been bisected as "direct" and "indirect" effects. In this study, we call the effect of the cash dividend policies on investments via financial and liquidity constraints as "direct effect" and the effect of the policies on the accumulation via market value and business reputation as "indirect effect".

Obtained results show that the indirect effect is positive, whereas the direct effect is negative. However, the magnitude of the direct effect is larger than that of the indirect. Therefore, the total effect of cash dividend policies on the accumulation of capital and investments is negative.

The fact that movements in stock prices of firms have an effect on the capital accumulation has shown that the financial markets could affect real economic variables. Also, the results that the cash dividend policies positively affect the market value of firms are mounting evidence to the validity of Signalling and Information Content Approach and Bird in Hand Theory. .
\end{abstract}

Keywords

Capital Accumulation, Dividend Payouts, Financial Constraints, Market Value of Firms, System in GMM

\section{Introduction}

Financial management consists of three main factors. These factors are investment, financing and dividend policies. While none of these factors is superior or inferior to others, they affect each other. Therefore, dividend policies affect capital accumulation via investment policies and financial policies.

Cash dividend payouts cause cash outflows from firms. Out-flows of cash resources decrease capability of financing of the firms especially that have limited borrowing opportunity.

* This study has been derived from Ph.D. dissertation of Mustafa ÇAYIR at Ege University.

1 Corresponding Author: Mustafa Çayır (Asst. Prof. Dr.), Artvin Coruh University, School of Applied Sciences and/or Banking and Finance, Artvin, Turkey. E-mail: mustafacayir@artvin.edu.tr ORCID: 0000-0001-8744-631X

2 Nasuh Oğuzhan Altay (Prof. Dr.), Ege University, Faculty of Economics and Administrative Sciences and/or Economics, İzmir, Turkey. E-mail: oguzhan.altay@ege.edu.tr ORCID: 0000-0000-0000-0000

To cite this article: Cayir, M., \& Altay, N. A. (2021). Direct and Indirect Effects of Cash Dividend Policies on Firms' Capital Accumulation in Selected Developed Markets. Istanbul Business Research, 50(2), 235-254. http://doi.org/10.26650/ibr.2021.50.884183 
A decrease in financing capability causes the firms postpone or cancel investments (Fazzari et al., 1988, p.183-4), (Cleary, 1999, p.685), (Alti, 2003, p.721), (Moyen, 2004, p.2075) and (Moyen and Platikanov, 2013, p.44-5). In addition, even if firms have borrowing capacity, there are usually some differences between borrowing cost and the cost of equity. The cost of internal funds is almost always lower than the external funds' cost. (Opler et al., 1999, p.4-9), (Chay and Suh, 2009, p.88), (Denis and Sibilkov, 2010, p.247), (Harford et al., 2014, p.978) and (Duong et al., 2020, p.2). Thus, if a firm prefers borrowing to equity in the financing of investment, the firm's weighted average cost of capital will be raised, and as a result of this, the firm's investment will go down. On the other hand, lots of studies in the relevant literature state that excess cash holding firms have been faced with the agency problem such as Jensen (1986), Harford (1999), Dittmar and Mahrt-Smith (2007), Harford et al. (2008) and Denis and Sibilkov (2010).

Within the frame of explanations in the previous paragraph, many studies have discussed the relationship between growth opportunities, investment decisions and cash dividend policy. Also, lots of papers have presented theoretical and empirical evidence about the relevant field. In this framework, Abor and Amidu (2006) determined a negative relationship between dividend payouts and growth. Also, a negative relationship between dividend yield and the growth opportunities was stated by Gul (1999), Gul and Kealey (1999) and (Danila et al., 2020). (Harakeh, 2020) shows that dividend policy has a constraining effect on corporate investment via information asymmetry and agency problems. Besides, a negative relationship has been found between investment opportunity set and dividend payout policy by Abor and Bokpin (2010) and Jabbouri (2016). On the other hand, some studies in the literature have reached different results about the relationship between growth and dividend policy. For instance, there is no significant relationship between dividend policy and firm growth according to Ressy and Chariri (2013). Also, Ghosh and Sun (2014) demonstrated that there is a statistically significant positive relationship between externally financed growth and dividend payments for REITs.

It's thought that dividend policies affect stock prices and there are many theoretical approaches to the explanation of this effect. The approaches are listed below:

- Irrelevance Theory: This theory suggests that the market value of the firms and the stock prices determined by the expected return and any other variable cannot influence the market value (Modigliani and Miller, 1958, p.265). In this context, dividend policies do not affect the market value of the firms.

- Signalling and Information Content Approach: This approach is based on information asymmetry and imperfection of the financial markets (Ross, 1977, p.39). Firms' managers have more information than the stockholders about firms' current and future situations. For this reason, dividend policies provide information to the 
market and stockholders. An increase in dividend payout ratio of a firm creates an expectation that increases the firm's income in the future. And so, the firm's market value is influenced by the expectation as positive. From this point of view, a raise in the dividend payout ratio increases the market value and stock price of the firms.

- Bird in Hand Theory1: Stockholders would prefer the profits made by the firms being under their own control rather than the firms' control. Because, it's dubious whether or not the firms will distribute the profit in the future and the future includes uncertainty and risk. Therefore, stockholders would like the distribution of profits as immediate as possible. Within this scope, the stocks of firms with high dividend payout ratio are traded at a lower discount rate than the stocks of firms with low dividend payout ratio.

- Tax Differential Theory: This theory is based on the idea that the capital gains and dividends are taxed at different rates. For instance, if the public authority excised dividends at a higher rate than capital gains, stocks of firms with high dividend payout ratio would be traded at a discounted price (vice versa). Then, the difference in the rate of taxation between dividends and capital gains can affect stock prices and dividend decisions of the firms (Farrar and Selwyn, 1967, p.453-4) and (Brennan, 1970, p.426).

- Clientele Effect2: Like the whole economy, stock market investors also consist of different social groups and levels of income. Each social and income group are in different tax brackets and expectations. For this reason, some of the investor groups prefer stocks of firms with high dividend payout ratios, and the others prefer stocks of firms with low dividend payout ratios or non-dividend-payers. In that case, according to the Clientele Effect, whether dividend payments increase share prices can't be generalized and this depends on dividend expectation of investors.

- Catering Theory: Actually, Catering Theory is a continuation and generalised form of Clientele Effect. Implementation of dividend policies by firms must satisfy expectations and serve the interests of shareholders according to Catering Theory. And different from the Clientele Effect, Catering Theory suggests that expectations and interests of shareholders change over time. Therefore, before deciding a dividend premium on stock prices, firm managers must also be aware of the change in shareholders' expectations and interests, in short, they must give the shareholders what they currently want. (Fama and French, 2001), (Baker and Wurgler 2004a, p.287) and (Baker and Wurgler, 2004b, p.1160-1).

1 The Theory was constructed by Myron J. Gordon and John Lintner. For details; Gordon (1959) and Lintner (1962).

2 For details; Allen, F. and Michaely, R. (2003), and Berk, J. and DeMarzo, P. (2017). 
There is a considerable amount of empirical evidence that a relationship exists between stock price movements and capital accumulation of firms. Bischoff (1970) puts forward that firms' dividend-price ratio is the best measure of the cost of capital. Bosworth (1975) suggests that Bischoff's results are valid just in the long run. If the stock markets adjust themselves so quickly, because temporary price movements of stocks at the short-term can't influence the fundamentals of firms, the managers won't scrap investment plans (Bosworth, 1975, p.286). Firm managers are willing to make their investment when the expected returns on marginal investment plans are higher than the shares yield on the existing capital stock. On the other hand, the rational managers would purchase either their or other firms' shares when marginal investment projects had a lower return than that of shares. (Fisher and Merton, 1984, p.36-41). All these results are corroborated by Barro (1990), Galeotti and Schiantarelli (1994) and Durham (2000), while Blanchard et al. (1993) and Bolbol and Omran (2005) are in opposition to the results.

The relationship between growth opportunities, the investment decision, capital accumulation of firms and dividend policy has been investigated in a single-sided approach in the literature up to now. However, we investigate the relationship between dividend policy and capital accumulation with a dual-sided view. Therefore, our main contribution to the literature is to investigate cash dividend policy with a dual-sided view as the cash constraining effect of dividend policy and the price effect of dividend policy on capital accumulation.

In the light of the explanations above, on the one hand, dividend policies influence investment and capital accumulation of firms via capability of financing or financing constraints which are called "direct effects" in this paper, and on the other hand, dividend policies can affect the market value of the firms. At this point, considering that the firms' market value is related to investment, dividend policies must affect capital accumulation via stock prices, which is called "indirect effects" in the paper. From this point of view, the primary aim and the main contribution of this study is: (1) to distinguish the effects of dividend policies on capital accumulation as "direct effects" and "indirect effects", and also (2) to detect the total effects of dividend policies on the capital accumulation. Therefore, we have developed the following hypotheses.

Hypothesis - I: Cash dividend payments affect the capital accumulation and growth of firms with two-ways as "direct" and "indirect".

Hypothesis - II: The direct effect of cash dividend payments on capital accumulation and growth is negative.

Hypothesis - III: The indirect effect of cash dividend payments on capital accumulation and growth is positive. 
Hypothesis - IV: The mathematical sign of the total effect of cash dividend payments on capital accumulation and growth varies depending on which effect is greater.

The next section describes the models that reveal the effects of dividend policies on the capital accumulation and market value of firms along with variables and dataset. The employed econometric method is discussed, and the empirical results reached are reported in Section 3. Finally, Section 4 includes concluding remarks of the study.

\section{Models and Dataset}

We established two different models in the present study with the help of the theoretical approaches and studies from the relevant literature. One of the models (Model (1)) has aimed for the explanation of the effects of dividend policies on the capital accumulation. The p urpose of the other model (Model (2)) is to reveal dividend policies' effects on the market value of firms. Abbreviations of the variables used in Model (1), Model (2) and all of the result tables have been presented Table 1 which takes part in "Tables" of the study.

Table 1

Abbreviations of the Variables Used in the Result Tables

\begin{tabular}{|c|c|c|c|}
\hline \multicolumn{2}{|l|}{ Variables } & \multicolumn{2}{|c|}{ Abbreviations } \\
\hline Constant & & \multicolumn{2}{|c|}{$\mathrm{C}$} \\
\hline ( $\Delta$ (Capital Stock) / Capital Stock $)$ & & \multicolumn{2}{|c|}{$\delta \mathrm{K} / \mathrm{K}$} \\
\hline (Market Value / Book Value) & & \multicolumn{2}{|c|}{$\mathrm{MV} / \mathrm{BV}$} \\
\hline (Cash Flow / Capital Stock) & & \multicolumn{2}{|c|}{$\mathrm{CF} / \mathrm{K}$} \\
\hline (Sales / Capital Stock) & & \multicolumn{2}{|c|}{$\mathrm{S} / \mathrm{K}$} \\
\hline (Cleary, 1999) & & \multicolumn{2}{|c|}{ CLRY } \\
\hline$(\Delta($ Stock Price $) /$ Stock Price $)$ & & \multicolumn{2}{|c|}{$\delta \mathrm{P} / \mathrm{P}$} \\
\hline (Cash Dividend Paid / Total Profit) & & \multicolumn{2}{|c|}{ CDPR } \\
\hline (Return On Equity) & & \multicolumn{2}{|c|}{ ROE } \\
\hline (Leverage Ratio) & & \multicolumn{2}{|c|}{ LR } \\
\hline$(\Delta$ (Total Profit) / Total Profit) & & \multicolumn{2}{|c|}{$\delta \pi / \pi$} \\
\hline$(\Delta$ (Total Assets) / Total Assets) & & \multicolumn{2}{|c|}{$\delta \mathrm{TA} / \mathrm{TA}$} \\
\hline 2010 Dummy & 2011 Dummy & $\mathrm{t}-10$ & $\mathrm{t}-11$ \\
\hline 2012 Dummy & 2013 Dummy & $\mathrm{t}-12$ & $\mathrm{t}-13$ \\
\hline 2014 Dummy & 2015 Dummy & $\mathrm{t}-14$ & $\mathrm{t}-15$ \\
\hline United States Dummy & United Kingdom Dummy & $\mathrm{d}-\mathrm{US}$ & $d-U K$ \\
\hline Japan Dummy & France Dummy & $\mathrm{d}-\mathrm{JP}$ & $\mathrm{d}-\mathrm{FR}$ \\
\hline
\end{tabular}

Model (1) is as follows:

$$
\begin{gathered}
\Rightarrow\left(\frac{\delta K}{K}\right)_{i, t}=C+\beta_{1.1}\left(\frac{M V}{B V}\right)_{i, t}+\beta_{1.2}\left(\frac{C F}{K}\right)_{i, t-1}+\beta_{1.3}\left(\frac{S}{K}\right)_{i, t-1}+\beta_{1.4}(C L R Y)_{i, t}+ \\
\beta_{1.5}\left(\frac{\delta P}{P}\right)_{i, t}+\beta_{1.6}(C D P R)_{i, t}+\beta_{1.7}(t-10)+\beta_{1.8}(t-11)+\beta_{1.9}(t-12)+\beta_{1.10}(t-13)+\beta_{1.11}(t-14)+ \\
\beta_{1.122}(t-15)+\beta_{1.13}(d-U S)+\beta_{1.14}(d-U K)+\beta_{1.15}(d-J P)+\beta_{1.16}(d-F R)+\varepsilon_{i, t}
\end{gathered}
$$




\section{$\left(\frac{\delta K}{K}\right)$}

is the logarithmic difference in total capital of the firms between periods $t$ and $t-1$. The variable indicates the rate of the firms' capital accumulation.

$\left(\frac{M V}{B V}\right)$ is

is used as investment opportunity set beside Tobin's $\mathrm{q}^{3}$ by some studies from existing literature such as Aivazian et al. (2003). Higher investment opportunities must be a reason for higher actual investments. In that case, the relationship between $\left(\frac{M V}{B V}\right)$ and investments of firms should be in the same direction. Therefore, we expect that the sign of the coefficient $\left(\beta_{1.1}\right)$ will be positive.

$\left(\frac{C F}{K}\right)$ is the representation of liquidity and cash making capability of the firms. There is a considerable amount of study which reveals that liquidity or cash flow affects firms' investment, at least dividend payments and financial constraints. Fazzari et al. (1988) and Agca and Mozumdar (2017), respectively, are two of the most prominent and the latest instances of relevant literature. Cash-rich firms can make more investment expenditures than cash-poor ones. Thus, $\beta_{1.2}$ must be positive as supported by Fazzari et al. (1988), Moyen (2004), Hirth and Viswanatha (2011) and Agca and Mozumdar (2017) like many others in the existing literature. Finally, due to the endogeneity problem, lagged values of the variable are used in the model.

$\left(\frac{S}{K}\right)$

consists of sales revenue over the capital stock. The variable stands for the market demand for the goods produced by the firms. Harrod (1939) and Domar (1946) claim that the market demand determines the capital accumulation, and the capital accumulation moves in the same direction with the market demand. In that case, in a similar manner to $\left(\frac{C F}{K}\right),\left(\frac{S}{K}\right)$ shows up as a Keynesian variable which is the indicator of demand. Within this scope, we expect a positive relationship between $\left(\frac{S}{K}\right)$ and the capital accumulation.

(CLRY) is a financing constraint index ${ }^{4}$ revealed by Cleary (1999). The decrease in the values of Cleary financing constraint index reduces the firms' financing capacity. On the other hand, an increase in the financing capacity must enhance the investment expenditures and the capital accumulation. Within this framework, the sign of $\beta_{1.4}$ is expected to be positive.

$\left(\frac{\delta P}{P}\right)$ is

is the logarithmic difference in stock prices of firms from period t- 1 to t. As we

3

Tobin q; . There are some measurement errors in the calculation of Tobin's q., instead of Tobin's q, is selected as a variable which represents the investment opportunity set in the model due to the dubious situation of Tobin's q. 
mentioned in the introduction of the study, stock price movements can affect the accumulation of capital. The stock prices or the market value is an indicator of the business reputation of the firms. Also, an increase in the market valuation raises the business reputation and commercial credit of the firms. The firms with high business reputation can reach sources of credit easier and at a lower cost than others. Therefore, stock price movements must affect capital accumulation in the same direction. For these reasons, we anticipate that the sign of $\beta_{1.5}$ will be positive. Also, $\left(\frac{\delta P}{P}\right)$ is used as an independent variable in the Model (2) that is established in order to expose indirect effects of dividend policies on capital accumulation.

$(C D P R)$ is the amount of cash dividend paid over the total profit of firms. The variable that is called "cash dividend payout ratio" is used in the Model (1) and Model (2) as a proxy for cash dividend policies of firms. Cash dividend payouts cause cash outflows from firms, and by doing so decrease cash resources of the firms. Therefore, for Model (1), it can be expected that there is a negative relationship between cash dividend payout ratio and the capital accumulation rate of the firms. On the other hand, for Model (2), it depends on the validity of the theoretical approaches which are used in the investigation on the relationship between stock price movements and the dividend policies. In consequence, there is no expectation about whether a positive or negative relationship exists between stock returns and the dividend policies, if there is a significant relationship.

Model (2) is as follows:

$$
\begin{gathered}
\Rightarrow\left(\frac{\delta P}{P}\right)_{i, t}=C+\beta_{2.1}(C D P R)_{i, t}+\beta_{2.2}(R O E)_{i, t}+\beta_{2.3}(L R)_{i, t}+\beta_{2.4}\left(\frac{\delta \pi}{\pi}\right)_{i, t}+ \\
\beta_{2.5}\left(\frac{\delta T A}{T A}\right)_{i, t}+\beta_{2.6}\left(\frac{\delta P}{P}\right)_{i, t-1}+\beta_{2.7}(t-10)+\beta_{2.8}(t-11)+\beta_{2.9}(t-12)+\beta_{2.10}(t-13)+ \\
\beta_{2.11}(t-14)+\beta_{2.12}(t-15)+\beta_{2.13}(d-U S)+\beta_{2.14}(d-U K)+\beta_{2.15}(d-J P)+\beta_{2.16}(d-F R)+\varepsilon_{i, t}
\end{gathered}
$$

$(R O E)$ can be defined as the net income over the shareholder's equity of the firms. Also, ROE has been used as an indicator of firms' performance in the relevant literature as well as return on assets, net profit margin, and earnings per share. An improvement in a firm's performance must raise the stock price of the firm. Therefore, we can expect that $\beta_{2.2}$ will be positive.

$(L R)$ shows how much capital comes from external sources and equities. The leverage ratio is also known as the financial leverage ratio. Also, the leverage ratio has been obtained by the total debt over the total equity of the firms. Firms' indebtedness goes up when there is an increase in the leverage ratio of firms. Going up (going down) in the indebtedness means that there is an increase (decrease) in the risk of firms' payments failure . Hence, the relationship between leverage ratio and stock return or $\beta_{2.3}$ coefficient must be negative in theory. 


$$
\left(\frac{\delta \pi}{\pi}\right)
$$

ned before, the Irrelevance Theory asserts that stock or market prices of firms are determined by the expected returns. If the assertion of the $t$ heory is true, the coefficient of the variable will be positive. In other words, we can say that when the firm's profit increases, the stock price of the firm must also rise.

$\left(\frac{\delta T A}{T A}\right)$ is the logarithmic difference in total assets of the firms from period $\mathrm{t}-1$ to $\mathrm{t}$. The variable represents the proportional change in firms' size over time. The increase in total assets must enhance the income generating ability of the firms. Therefore, the coefficient sign of $\left(\frac{\delta T A}{T A}\right)$ or the relationship between stock return and change in total assets of the firms must be positive.

Lagged values of stock returns were used as an independent variable in the models that are established for the explanation of current stock returns by lots of studies in the relevant literature like Zhou and Ruland (2006) and Huang et al. (2009). Indeed, shareholders pay regard to the previous returns of shares when investing in a stock. Within this scope, Model (2) established by us, includes a variable that has one period of lagged values of stock returns. On the other hand, each economy has different agendas, cycles, and also business, political and social processes each year. Thus, Model (1) and (2) have included both the time dummies and the market dummy variables.

The dataset used in the study consists of annual observations between 2010 and 2015 of 683 non-bank firms selected from S\&P 500, FTSE 100, Nikkei 225 and CAC 40 indexes. In the selection process of the firms, special attention has been paid that the firms had been listed at least once in the relevant indexes, through the period from 2010 to 2015. In this context, respectively, 372, 87, 184 and 40 of 683 non-bank firms come from S\&P 500, FTSE 100, Nikkei 225 and CAC 40 indexes. The total market cap ratio of the relevant indexes and their countries is above $70 \%$ of the world's market cap. Also, the relevant countries are the four biggest markets all over the world in market cap. Within this scope, for their representative power to the world, we have selected the markets for our analyses. ${ }^{5}$ At the end of the section, we would like to point out that all of the data used in analysis (1) and (2) were taken from the Thomson Reuters (Datastream) database.

5 For details; https://www.weforum.org/agenda/2015/08/what-the-world-would-look-like-if-countries-were-the-sizeof-their-stock-markets?utm_content=bufferba473\&utm_medium=social\&utm_source=facebook.com\&utm campaign= buffer. 


\section{Econometric Method and Empirical Results}

First of all, we should indicate that there are some missing values in the dataset, which means that the type of dataset is an unbalanced panel. First-differences of variables augment missing observations in the unbalanced panel datasets. Two equations are constituted by the lagged values of first-differenced variables for the level equations and the lagged values of level variables for the first-differenced equations. Then, both equations are estimated together to minimise the missing observations. The econometric method that estimated the equations both together is called the "System in Generalized Method of Moments (GMM)".6 On the other hand, the number of the cross-section (683) is larger than the number of time series (6) of the dataset. Also, both Model (1) and (2) include endogenous variables. The System in GMM has been preferred in the econometric estimation of the models due to the above mentioned reasons.

The econometric analyses 7 were made in Stata 13 software using the "xtabond2" command that was developed by Roodman. Roodman's command makes an estimation that is robust to heteroscedasticity and autocorrelation. Also, it allows more diagnostic tests than the other GMM estimator commands. (Roodman, 2009, p.128-9). In addition to them, we have used the technique developed by Windmeijer 8 to make an efficient calculation of standard errors.

Summary statistics in Table 2 has been obtained from the annual data belonging to 683 non-bank firms operating in the United States, United Kingdom, Japan and France at the period of 2010-2015.

Table 2

Summary Statistics

\begin{tabular}{|c|c|c|c|c|}
\hline \multicolumn{5}{|c|}{ DEVELOPED MARKETS (US - UK - JP - FR) } \\
\hline \multicolumn{5}{|c|}{ Analysis (1) } \\
\hline Variable & Mean & Standard Deviation & Minimum & Maximum \\
\hline$\delta \mathbf{K} / \mathbf{K}$ & 0.03 & 0.187 & -2.207 & 1.573 \\
\hline $\mathbf{M V} / \mathbf{B V}$ & 2.463 & 6.189 & -326.08 & 52.497 \\
\hline CF/K (-1) & 0.147 & 0.098 & -0.615 & 1.528 \\
\hline $\mathrm{S} / \mathrm{K}(-\mathbf{1})$ & 1.294 & 0.912 & 0.089 & 18.096 \\
\hline CLRY & 0.205 & 0.308 & -0.926 & 1.319 \\
\hline$\delta \mathbf{P} / \mathbf{P}$ & 0.058 & 0.258 & -0.886 & 0.945 \\
\hline CDPR & 0.442 & 3.019 & -3.09 & 131.1 \\
\hline \multicolumn{5}{|c|}{ Analysis (2) } \\
\hline$\delta \mathrm{P} / \mathrm{P}$ & 0.05 & 0.29 & -2.558 & 1.409 \\
\hline
\end{tabular}

6 For details; Arellano and Bover (1995) and Blundell and Bond (1998).

7 Outlier observations at the dataset were determined with the "bacon" command. And then, the determined observations as outliers were removed from the dataset. See for details Weber (2010) about the "bacon" command.

8 See for details of Windmeijer Correction; Windmeijer (2005). 


\begin{tabular}{lcccc}
\hline Variable & Mean & Standard Deviation & Minimum & Maximum \\
\hline CDPR & 0.441 & 2.994 & -3.09 & 131.102 \\
ROE & 0.149 & 0.351 & -13.109 & 10.897 \\
LR & 0.259 & 0.146 & 0 & 0.795 \\
$\boldsymbol{\delta} \boldsymbol{\pi} / \boldsymbol{\pi}$ & 0.081 & 0.305 & -1.016 & 1.21 \\
$\boldsymbol{\delta}$ TA/TA & 0.021 & 0.102 & -0.341 & 0.404 \\
$\boldsymbol{\delta P / P ( - 1 )}$ & 0.076 & 0.279 & -2.558 & 1.409 \\
\hline
\end{tabular}

The expression "(-1)" next to the variables shows that one lagged values of the variables are used.

The firms in the database had accumulated capital average $3 \%$ per year during the period of 2010-2015. Also, the stock prices of the firms had gone up on average $5 \%$ per year during the same period. Furthermore, the firms had paid on average $44.15 \%$ of their total profits as cash dividend per year of the relevant period.

Correlations between the variables used in Model (1) and (2) are shown in Table 3. Variance inflation factor tests ${ }^{9}$ show that there is a considerable risk of multicollinearity due to the high correlations between some variables. Therefore, $\mathrm{CF} / \mathrm{K}, \delta \mathrm{P} / \mathrm{P}$, and CDPR were normalised at Analysis (1). On the other hand, CDPR, LR, and $\delta \pi / \pi$ were normalised at Analysis (2). Multicollinearity was not determined by the employed tests of variance inflation factor after the normalisation process of relevant variables.

Table 3

Correlation Matrices

\begin{tabular}{|c|c|c|c|c|c|c|c|}
\hline \multicolumn{8}{|c|}{ DEVELOPED MARKETS (US - UK - JP - FR) } \\
\hline \multicolumn{8}{|c|}{ Analysis (1) } \\
\hline & $\delta \mathbf{K} / \mathbf{K}$ & MV/BV & CF/K (-1) & $\mathrm{S} / \mathrm{K}(-1)$ & CLRY & $\delta \mathbf{P} / \mathbf{P}$ & CDPR \\
\hline$\delta \mathbf{K} / \mathbf{K}$ & 1 & & & & & & \\
\hline $\mathbf{M V} / \mathbf{B V}$ & 0.233 & 1 & & & & & \\
\hline $\mathrm{CF} / \mathrm{K}(-1)$ & 0.166 & 0.006 & 1 & & & & \\
\hline $\mathrm{S} / \mathrm{K}(-\mathbf{1})$ & 0.014 & 0.146 & 0.032 & 1 & & & \\
\hline CLRY & 0.37 & 0.393 & 0.048 & -0.291 & 1 & & \\
\hline$\delta \mathbf{P} / \mathbf{P}$ & 0.103 & 0.146 & -0.092 & -0.073 & 0.099 & 1 & \\
\hline CDPR & -0.071 & 0.005 & -0.01 & -0.021 & -0.026 & -0.031 & 1 \\
\hline \multicolumn{8}{|c|}{ Analysis (2) } \\
\hline & $\delta \mathbf{P} / \mathbf{P}$ & CDPR & ROE & LR & $\delta \pi / \pi$ & бTA/TA & $\delta \mathrm{P} / \mathrm{P}(-1)$ \\
\hline$\delta \mathbf{P} / \mathbf{P}$ & 1 & & & & & & \\
\hline CDPR & -0.125 & 1 & & & & & \\
\hline ROE & 0.169 & -0.027 & 1 & & & & \\
\hline LR & -0.163 & 0.155 & 0.037 & 1 & & & \\
\hline$\delta \pi / \pi$ & 0.241 & -0.299 & 0.022 & -0.065 & 1 & & \\
\hline$\delta$ TA/TA & 0.233 & -0.092 & 0.254 & 0.06 & 0.111 & 1 & \\
\hline$\delta P / P(-1)$ & 0.098 & -0.052 & 0.246 & -0.091 & 0.085 & 0.071 & 1 \\
\hline
\end{tabular}

The expression "(-1)" next to the variables show that one lagged values of the variables are used.

Summary statistics and correlation matrices regarding variables used in the analyses were represented in Table 2 and Table 3, respectively. Results reached from the econometric analyses are going to be demonstrated in the rest of the paper.

9 Variance Inflation Factor Tests take part in Appendix of the paper. 
Results of the econometric analyses of both Model (1) and (2) estimated by System in GMM fall into Table 4. As it can be seen in the table, the signs of all coefficients of variables are in accordance with the theoretical expectations. Also, the coefficients of variables are statistically significant. Therefore, when the first variable of Model (1), namely MV/BV, increases, the rate of the capital accumulation goes up.

Table 4

Effects of Cash Dividend Policies on the Capital Accumulation and Firms'Market Value

\begin{tabular}{|c|c|c|c|}
\hline \multicolumn{4}{|c|}{$\begin{array}{l}\text { DEVELOPED MARKETS (US - UK - JP - FR) } \\
\text { (US - GB - JP - FR) }\end{array}$} \\
\hline Variable & System in GMM (1) & Variable & System in GMM (2) \\
\hline $\mathbf{C}$ & & $\mathbf{C}$ & $-0.103 * *(0.048)$ \\
\hline MV/BV & $0.012 *(0.007)$ & CDPR & $0.124 * * *(0.032)$ \\
\hline CF/K (-1) & $0.062 * *(0.025)$ & ROE & $1.292 * * *(0.187)$ \\
\hline $\mathrm{S} / \mathrm{K}(-1)$ & $0.035 *(0.021)$ & LR & $-0.137 * * *(0.05)$ \\
\hline CLRY & $0.275^{* * *}(0.78)$ & $\delta \pi / \pi$ & $0.247 * * *(0.039)$ \\
\hline$\delta \mathbf{P} / \mathbf{P}$ & $0.115 * * *(0.027)$ & $\delta$ ТА/TA & $0.36 * * *(0.086)$ \\
\hline CDPR & $-0.051 *(0.029)$ & $\delta P / P(-1)$ & $-0.251 * * *(0.097)$ \\
\hline$t-10$ & - & $t-10$ & - \\
\hline$t-11$ & $0.035 * *(0.014)$ & $\mathbf{t}-\mathbf{1 1}$ & - \\
\hline$t-12$ & $-0.003(0.011)$ & $t-12$ & $-0.153 * * *(0.018)$ \\
\hline$t-13$ & $-0.025 * *(0.012)$ & $t-13$ & \\
\hline$t-14$ & $-0.051 * * *(0.008)$ & $t-14$ & $-0.152 * * *(0.018)$ \\
\hline$t-15$ & - & $t-15$ & $-0,253 * * *(0,018)$ \\
\hline d - US & $-0.191 * * *(0.054)$ & $\mathbf{d}-\mathbf{U S}$ & $0.006(0.023)$ \\
\hline d - UK & $-0.204 * * *(0.054)$ & $\mathbf{d}-\mathbf{U K}$ & - \\
\hline $\mathbf{d}-\mathbf{J P}$ & $-0.136 * * *(0.038)$ & $\mathbf{d}-\mathbf{J P}$ & $0.099 * * *(0.024)$ \\
\hline d - FR & $-0.165 * * *(0.047)$ & d $-\mathbf{F R}$ & $0.048 *(0.029)$ \\
\hline
\end{tabular}

\begin{tabular}{lccccc}
\hline & \multicolumn{2}{c}{ Regression Diagnostic Tests } & & \multicolumn{2}{c}{ Regression Diagnostic Tests } \\
\hline Test & Test Statistic & Prob. Value & Test & Test Statistic & Prob. Value \\
\hline Wald Test & 422.31 & 0.000 & Wald Test & 562.84 & 0.000 \\
AR (1) & -7.93 & 0.000 & AR (1) & -4.08 & 0.000 \\
AR (2) & -1.28 & 0.201 & AR (2) & -1.22 & 0.223 \\
AR (3) & -1.29 & 0.198 & AR (3) & - & - \\
Sargan Test & 35.95 & 0.056 & Sargan Test & 36.25 & 0.052 \\
Hansen Test & 22.62 & 0.542 & Hansen Test & 23.78 & 0.474 \\
Data Set & \multicolumn{2}{c}{ Cross Section $=580$} & Data Set & Cross Section $=380$ \\
& Number of Observation $=2194$ & & Number of Observation $=1275$ \\
\hline
\end{tabular}

The numbers in brackets show the standard deviation of the coefficients at the table. "***”, "**” and "*” symbols indicate respectively, $1 \%, 5 \%$ and $10 \%$ statistical significance of the coefficients. Also, exclusive Hansen Tests' results belonging to variables are reported in the Appendix of the paper. On the other hand, the rate of capital accumulation $(\delta \mathrm{K} / \mathrm{K})$ is independent variable at the analysis $(1)$ and proportional change in firms' value $(\delta \mathrm{P} / \mathrm{P})$ is independent variable at the analysis (2). Finally, the expression "(-1)" next to the variables shows that one lagged values of the variables are used in the regressions.

An increase in $\mathrm{CF} / \mathrm{K}$ and $\mathrm{S} / \mathrm{K}$ enhances the accumulation of capital at the subsequent term. However, the sensitivity of capital accumulation to $\mathrm{CF} / \mathrm{K}$ is almost two times higher than that of $\mathrm{S} / \mathrm{K}$. Also, CLRY can affect the capital accumulation of firms. According to this result, an increase in the constraint of firms' financing reduces capital accumulation of the firms. In this 
context, it can be said that the Cleary financial constraint index is a useful indicator of financial constraints in view of the statistical significance of the coefficient. In addition to them, CLRY is the most sensitive variable to the capital accumulation in comparison with $\mathrm{CF} / \mathrm{K}$ and $\mathrm{S} / \mathrm{K}$. Achieved results on the variables $\mathrm{CF} / \mathrm{K}, \mathrm{S} / \mathrm{K}$ and CLRY are consistent with Fazzari et al. (1988), Moyen (2004), Bolbol and Omran (2005), Moyen and Platikanov (2013) and the overwhelming majority of relevant literature.

An increase in ROE, which is an indicator of the firm performance, enhances the market value of firms. While our results about ROE are consistent with a part of literature like Ahsan (2012), they are incompatible with some other studies like Anwaar (2016). On the other side, when the indicator of firms' indebtedness LR goes up, stock prices of firms come down. So, we can say that there is a negative relationship between the level of indebtedness and the market values of the firms. While the result is supported by some studies in the literature like Shah and Noreen (2016), some others, like Zhou and Ruland (2006), stand against it.

$\delta \pi / \pi$ and $\delta \mathrm{TA} / \mathrm{TA}$ influence the market values of the firms positively. According to these results, if a firm's profits increase $1 \%$, the market value of the firm goes up about $0.247 \%$. Likewise, if the firm's total assets increase $1 \%$, stock prices of the firm rise roughly 0.36 $\%$. Our results about profits and total assets of firms are consistent with Huang et al. (2009), Hunjra et al. (2014), and Shah and Noreen (2016).

According to the results in this paper, when the increase in the market value of the firm is $100 \%$, the capital accumulation rate of a firm raises about $11.5 \%$. Then, it can be said that pricing in the financial markets affects real economic indicators like investment expenditures, credit costs and capabilities via the business reputation of corporations. Also, movements in the market values of firms have a negative effect on the subsequent market values of the firms to about $25 \%$ of the stock price movements. On the other hand, if a firm distributed all of its profits to shareholders as cash dividend, the capital accumulation rate of the firm would come down about $5.1 \%$. Also, the market value of the firm would rise about $12.4 \%$ in the same fiscal year.

Model (1) was established to determine the direct effects of the cash dividend on the capital accumulation. Also, as noted earlier, Model (2) is a mediation model that is an attempt to reveal indirect effects of the cash dividend on capital accumulation. Mediation models' independent variables take part as a dependent variable in the base models. If there are two equations, and one of them is a mediation equation like below, direct effects must be calculated as follows according to Sobel (1982). 


$$
\begin{aligned}
& Y=C_{1}+\beta_{1} X_{1}+\beta_{2} X_{2}+\beta_{3} X_{3}+\ldots . .+\varepsilon_{1} \\
& \Rightarrow \text { Direct Effect }: X_{3} \underset{\left(\beta_{3}\right)}{\longrightarrow} Y \\
& X_{2}=C_{a}+\beta_{a} X_{a}+\beta_{b} X_{b}+\beta_{c} X_{3}+\ldots . .+\varepsilon_{a} \\
& \Rightarrow \text { Indirect Effect }: X_{3} \underset{\left(\beta_{c}\right)}{\longrightarrow} X_{2} \underset{\left(\beta_{2}\right)}{\longrightarrow} Y
\end{aligned}
$$

$$
\beta_{\text {indirect }}=\beta_{\mathrm{c}} \times \beta_{2}, \quad \text { Total Effect : } \beta_{3}+\beta_{\text {indirect }}
$$

In the present case, direct effects, indirect effects, and the sum of the effects of the cash dividend policies on the capital accumulation of firms are in Table 5.

Table 5

Direct, Indirect, and Total Effects of Cash Dividend Policies on Capital Accumulation

\begin{tabular}{lcc}
\hline & Variables & Developed Markets (US - GB - JP $-\mathbf{F R})$ \\
\hline Direct Effects & $\mathbf{C D P R} \rightarrow \boldsymbol{\delta} \mathbf{K} / \mathbf{K}$ & -0.051 \\
$\boldsymbol{\delta} \mathbf{P} / \mathbf{P} \rightarrow \boldsymbol{\delta} \mathbf{K} / \mathbf{K}$ & 0.115 \\
$\mathbf{C D P R} \rightarrow \boldsymbol{\delta P} / \mathbf{P}$ & 0.124 \\
Indirect Effects & $(\mathbf{C D P R} \rightarrow \boldsymbol{\delta P} / \mathbf{P}) \times(\boldsymbol{\delta P} / \mathbf{P} \rightarrow \boldsymbol{\delta K} / \mathbf{K})$ & $0.124 \times 0.115=0.014$ \\
Sum of the Effects & Direct Effects + Indirect Effects & $-0.051+0.014=-0.037$ \\
\hline
\end{tabular}

It is clear from Table 5 that the direct effect of cash dividend policies on capital accumulation is about negative $5.1 \%$. Also, the indirect effect of cash dividend policies upon the capital accumulation is obtained by multiplying the influence of cash dividend policies upon the market values of firms by the impact of market values on the accumulation of capital. Therefore, the cash dividend policies have a positive indirect effect on the capital accumulation of about $1.4 \%$, which is obtained by multiplying $12.4 \%$ by $11.5 \%$ as pointed out above.

Finally, the total effect of the cash dividend policies on the accumulation consists of the summation of direct and indirect effects. Hereunder, the total effect, - $5.1 \%$ (direct effect) plus $1.4 \%$ (indirect effect), is equal to $-3.7 \%$. In that case, cash dividend policies have about $3.7 \%$ negative effect on the capital accumulation.

\section{Conclusion}

The effects of cash dividend policies on the capital accumulation of non-bank firms operating in The United States (S\&P 500), The United Kingdom (FTSE 100), Japan (Nikkei 225) and France (CAC 40) have been investigated in this study. Different from relevant literatu re, in this paper we bisected the "total effect" of cash dividend policies on investments or capital accumulation as "direct effect" and "indirect effect".

Cash dividend payouts cause cash outflows from firms, and as a result of this, they operate under these financial constraints. For this reason, firms squeeze investment expenditures 
and reduce capital accumulation as long as there is an increase in cash dividend payout ratio which is used as the dividend policy variable. In the study, we called the effect of the cash dividend policies on investments via financial and liquidity constraints "direct effect".

On the other hand, cash dividend payouts have a positive effect on market values or stock prices of firms. Also, according to the empirical results, market values of firms affect investment expenditures and capital accumulation via business reputation and capital cost. Therefore, cash dividend policies can influence the capital accumulation indirectly. In this paper, we called the effect of cash dividend policies on capital accumulation via market value, business reputation, and the capital cost "indirect effect".

The "total effect" of cash dividend policies on capital accumulation consists of the summation of "direct" and "indirect" effects. The "indirect effect" is positive, whereas the "direct effect" is negative. In addition to this, the magnitude of the direct effect is larger than that of the indirect. Thus, the "total effect" of cash dividend policies on the accumulation of capital and investments is negative in our sample, but it is not as much as the "direct effect". Within this framework, obtained results in our study about the "total effect" are consistent with results of the study that Abor and Amidu (2006), Gul and Kealey (1999), Danila et al. (2020) and Harakeh (2020). On the other hand, we could not find satisfactory evidence to support Ressy and Chariri (2013) and Ghosh and Sun (2014).

The fact that movements in stock prices of firms have an effect on the capital accumulation has shown that the financial markets could affect real economic variables like the investment expenditures. Also, the empirical results that the cash dividend policies positively affect the market value of firms are mounting evidence to the validity of Signalling and Information Content Approach and Bird in Hand Theory.

On the other hand, stock prices have been influenced by the return of firms. However, according to the obtained results, the market values or stock prices of the firms have been affected by not only returns but also some other variables. Therefore, our results have partially supported the Irrelevance theory in terms of the relationship between return and stock price of firms.

Peer-review: Externally peer-reviewed.

Conflict of Interest: The author has no conflict of interest to declare.

Grant Support: The author declared that this study has received no financial support.

Author Contributions: Conception/Design of study: M.Ç., N.O.A.; Data Acquisition: M.Ç.; Data Analysis/Interpretation: M.Ç., N.O.A.; Drafting Manuscript: M.Ç., N.O.A.; Critical Revision of Manuscript: M.Ç., N.O.A.; Final Approval and Accountability: M.Ç. 


\section{References}

Abor, J. Y., \&Amidu, M. (2006). Determinants of Dividend Payout Ratios in Ghana. The Journal of Risk Finance, 7(2), $136-145$.

Abor, J., \& Bokpin, G. A. (2010). Investment Opportunities, Corporate Finance, and Dividend Payout Policy: Evidence from Emerging Markets. Studies in Economics and Finance, 27(3), 180 - 194.

Agca, S., \& Mozumdar A. (2017). Investment - Cash Flow Sensitivity: Fact or Fiction. Journal of Financial and Quantitative Analysis, 52(3), 1111 - 41.

Ahsan, A. F. M. M. (2012). Can ROE be Used to Predict Portfolio Performance?. Economics, Management, and Financial Markets, 7(2), $132-48$.

Aivazian, V., Booth, L., \& Cleary, S. (2003). Do Emerging Market Firms Follow Different Dividend Policies from U.S. Firms?. The Journal of Financial Research, 26(3), 371 - 87.

Allen, F., \& Michaely, R. (2003). Payout Policy. Handbook of the Economics of Finance: Corporate Finance, Vol. 1A, ed. GM Constantinides, M Harris, RM Stulz, pp. 337 - 429. Amsterdam: North Holland.

Alti, A. (2003). How Sensitive is Investment to Cash Flow When Financing is Frictionless. The Journal of Finance, 58(2), $707-22$.

Anwaar, M. (2016). Impact of Firms' Performance on Stock Returns (Evidence from Listed Companies of FTSE-100 Index London, UK). Global Journal of Management and Business Research 16(1), 30 - 39.

Arellano, M., Bond, S. (1991). Some Tests of Specification for Panel Data: Monte Carlo Evidence and an Application to Employment Equations. The Review of Economic Studies, 58(2):, 277 - 97.

Arellano, M., Bover, O. (1995). Another Look at the Instrumental Variable Estimation of Error-Components Model. Journal of Econometrics, 68(1995), 29 - 51.

Baker, M., Wurgler, J. (2004a). Appearing and Disappearing Dividends: The Link to Catering Incentives. Journal of Financial Economics, 73(2004), 271 - 88.

Baker, M., Wurgler, J. (2004b). A Catering Theory of Dividends. The Journal of Finance, 59(3), 1125 - 65.

Barro, R. J. (1990). The Stock Market and Investment. The Review of Financial Studies., 3(1), 115 - 31.

Berk, J., DeMarzo, P. (2017). Corporate Finance, Vol 4: Harlow: Pearson Education Limited.

Bischoff, C. W. (1970). A Model of Nonresidential Construction in the United States. The American Economic Review, 60(2), $10-7$.

Blanchard, O., Rhee, C., \& Summers, L. (1993). The Stock Market, Profit, and Investment. The Quarterly Journal of Economics, 108(1), 115 - 36.

Blundell, B., \& Bond, S. (1998). Initial Conditions and Moment Restrictions in Dynamic Panel Data Models. Journal of Econometrics, 87(1998), 115 - 43.

Bolbol, A. A., \& Omran, M. M. (2005). Investment and the Stock Market: Evidence from Arab Firm-level Panel Data. Emerging Markets Review, 6(2005), 85 - 106.

Bosworth, B. (1975). The Stock Market and the Economy. Brookings Papers on Economic Activity, 1975(2), $257-300$.

Brennan, J. M. (1970). Taxes, Market Valuation and Corporate Financial Policy. National Tax Journal, 23(4), $417-27$.

Chay, J. B., \& Suh, J. (2009). Payout Policy and Cash-Flow Uncertainty. Journal of Financial Economics, $93,88-107$. 
Cleary, S. (1999). The Relationship Between Firm Investment and Financial Status. The Journal of Finance, 54(2), $673-92$.

Danila, N., Noreen, U., Azizan, N. A., Farid, M., Ahmed, Z. (2020). Growth Opportunities, Capital Structure and Dividend Policy in Emerging Market: Indonesia Case Study. Journal of Asian Finance Economics and Business, 7(10), $1-8$.

Denis, D. J., \& Sibilkov, V. (2010). Financial Constraints, Investment, and the Value of Cash Holdings. The Review of Financial Studies, 23(1), 247 - 269.

Dittmar, A., \& Mahrt-Smith, J. (2007). Corporate Governance and the Value of Cash Holdings. Journal of Financial Economics, 83, $599-634$.

Duong, H. N., Nguyen, J. H., Nguyen, M., \& Rhee, S. G. (2020). Navigating Through Economic Policy Uncertainty: The Role of Corporate Cash Holdings. Journal of Corporate Finance, 62, 1- 22.

Durham, J. B. (2000). Econometrics of the Effects of Stock Market Development on Growth and Private Investment in Lower Income Countries. Work. Pap. 53, Queen Elizabeth House.

Fama, E. F., \& French, K. R. (2001). Disappearing Dividends: Changing Firm Characteristics or Lower Propensity to Pay?. Journal of Financial Economics, 60(2001), 3 - 43.

Farrar, E. D., Farrar, F. D., Selwyn, L. L. (1967). Taxes Corporate Financial Policy and Return to Investors. National Tax Journal, 20(4), $444-54$.

Fazzari, S. M., Hubbard, R. G., Petersen, B. C., Blinder, A. S., Poterba, J. M. (1988). Financing Constraints and Corporate Investment, Brookings Papers on Economic Activity, 1988(1), 141 - 206.

Fischer, S., \& Merton, R. C. (1984). Macroeconomics and Finance: The Role of the Stock Market. Work. Pap. 1291, National Bureau of Economic Research.

Galeotti, M., \& Schiantarelli, F. (1994). Stock Market Volatility and Investment: Do Only Fundamentals Matter?. Economica, 61(242), $147-65$.

Ghosh, C., \& Sun, L. (2014). Agency Cost, Dividend Policy and Growth: The Special Case of REITs. J Real Estate Finan Econ, 48, $660-708$.

Gordon, M. J. (1959). Dividends, Earnings, and Stock Prices. The Review of Economics and Statistics, 41(2), $99-105$.

Gul, F. A. (1999). Growth Opportunities, Capital Structure and Dividend Policies in Japan. Journal of Corporate Finance, 5, $141-168$.

Gul, F. A., \& Kealey, B. T. (1999). Chaebol, Investment Opportunity Set and Corporate Debt and Dividend Policies of Korean Companies. Review of Quantitative Finance and Accounting, 13, $401-416$.

Harakeh, M. (2020). Dividend Policy and Corporate Investment Under Information Shocks. Journal of International Financial Markets, Institutions \& Money, 65, 1 - 21.

Harford, J. (1999). Corporate Cash Reserves and Acquisitions. The Journal of Finance, 54(6), 1969 - 1997.

Harford, J., Klasa, S., Maxwell, W. F. (2014). Refinancing Risk and Cash Holdings. The Journal of Finance, 69(3), $975-1012$.

Harford, J., Mansi, S. A., Maxwell, W. F. (2008). Corporate Governance and Firm Cash Holdings in the US. Journal of Financial Economics, 87, 535 - 555.

Harrod, R. F. (1939). An Essay in Dynamic Theory. The Economic Journal, 49(193), 14 - 33.

Hirth, S., Viswanatha, M. (2011). Financing Constraints, Cash - Flow Risk, and Corporate Investment. Journal of Corporate Finance, 17(2011), 1496 - 509.

Huang, C. S., You, C. F., \& Lin, S. H. (2009). Cash Dividends, Stock Dividends and Subsequent Earnings Growth. Pasific - Basin Finance Journal, 17(2009), 594 - 610. 
Hunjra, I. A., Ijaz, S. M., Chani, I. M., Hassan, U. S., \& Mustafa, U. (2014). Impact of Dividend Policy, Earning per Share, Return on Equity, Profit After Tax on Stock Prices. International Journal of Economics and Empirical Research, 2(3), 109 - 15.

Jabbouri, I. (2016). Determinants of Corporate Finance Dividend Policy in Emerging Markets: Evidence from MENA Stock Markets. Research in International Business and Finance, 37, 283 - 298.

Jensen, M. C. (1986). Agency Costs of Free Cash Flow, Corporate Finance, and Takeovers. The American Economic Review, 76(2), 323 - 329.

Lintner, J. (1962). Dividends, Earnings, Leverage, Stock Prices and the Supply of Capital to Corporations. The Review of Economics and Statistics, 44(3), $243-69$.

Miller, M. H., \& Modigliani, F. (1961). Dividend Policy, Growth, and the Valuation of Shares. The Journal of Business, 34(4), $411-33$.

Modigliani, F., \& Miller, M. H. (1958). The Cost of Capital, Corporation Finance and the Theory of Investment. The American Economic Review, 48(3), 261 - 97.

Moyen, N. (2004). Investment-Cash Flow Sensitivities: Constrained Versus Unconstrained Firms. The Journal of Finance, 59(5), $2061-92$.

Moyen, N., \& Platikanov, S. (2013). Investment and Financing Constraints. Journal of Accounting and Finance, 13(3), $29-50$.

Opler, T., Pinkowitz, L., Stulz, R., \& Williamson, R. (1999). The Determinants and Implications of Corporate Cash Holdings. Journal of Financial Economics, 52, 3 - 46.

Ressy, A. E., \& Chariri, A. (2013). Pengaruh Kinerja Keuangan Terhadap Kebijakan Dividen di Bursa Efek Indonesia. Diponegoro Journal of Accounting, 2(4), 1 - 10.

Roodman, D. (2009). How to do xtabond2: An Introduction to Difference and System GMM in Stata. The Stata Journal, 9(1), $86-136$.

Ross, S. A. (1977). The Determination of Financial Structure: The Incentive-Signalling Approach. The Bell Journal of Economics, 8(1), 23 - 40.

Shah, A. S., \& Noreen, U. (2016). Stock Price Volatility and Role of Dividend Policy: Empirical Evidence from Pakistan. International Journal of Economics and Financial Issues, 6(2), 461 - 72.

Sobel, M. E. (1982). Asymptotic Confidence Intervals for Indirect Effects in Structural Equation Models. Sociological Methodology, 13(1982), 290 - 312.

Weber, S. (2010). bacon: An Effective way to Detect Outliers in Multivariate Data Using Stata (and Mata). The Stata Journal, 10(3), $331-8$.

Windmeijer, F. (2005). A Finite Sample Correction for the Variance of Linear Efficient two-step GMM Estimators. Journal of Econometrics, 126(2005), 25 - 51.

Zhou, P., Ruland, W. (2006), Dividend Payout and Future Earnings Growth. Financial Analysts Journal, 62(3), $58-69$. 


\section{Appendix}

\section{A.1. Cleary Financing Constraint Index}

$\Rightarrow$ Cleary $=-0.017 \times$ Current Ratio $+0.0003 \times$ Fixed Charge Coverage Ratio

$+0.0007 \times \frac{\text { Slack }}{\text { Net Fixed Assets }}+3.904 \times$ Net Income Margin

$+0.467 \times \frac{\Delta(\text { Sales })}{\text { Sales }}-0.439 \times$ Leverage Ratio

$\Rightarrow$ Slack $=$ Cash and Short Term Investment +0.5 (Inventory $)$

+0.7 (Accounts Receivable) - Notes Payable 


\section{A.2. Variance Inflation Factor Tests (VIF Tests)}

Table A.2.1

VIF Test for Analysis (1)

\begin{tabular}{lcc}
\hline Variables & VIF & 1/VIF \\
\hline MV/BV & 4.13 & 0.242 \\
$\boldsymbol{\delta P / P}$ & 3.34 & 0.3 \\
$\mathbf{S} / \mathbf{K}$ & 3.27 & 0.306 \\
$\mathbf{C F} / \mathbf{K}$ & 2.56 & 0.39 \\
$\mathbf{C D P R}$ & 2.18 & 0.458 \\
$\mathbf{C L R Y}$ & 2.11 & 0.473 \\
Mean VIF & 2.55 & \\
\hline
\end{tabular}

Table A.2.2

VIF Test for Analysis (2)

\begin{tabular}{lll}
\hline Variables & VIF & $\mathbf{1 / V I F}$ \\
\hline ROE & 3.21 & 0.312 \\
LR & 2.43 & 0.412 \\
CDPR & 2.37 & 0.422 \\
$\boldsymbol{\delta} \boldsymbol{\pi} / \boldsymbol{\pi}$ & 2.27 & 0.441 \\
$\boldsymbol{\delta} \mathbf{P} / \mathbf{P}$ & 1.63 & 0.614 \\
$\boldsymbol{\delta}$ TA/TA & 1.16 & 0.863 \\
Mean VIF & 2.05 & \\
\hline
\end{tabular}




\section{A.3. The Results of Exclusive Hansen Tests}

Table A.3.1

Exclusive Hansen Test Results of Variables at Analysis (1)

\begin{tabular}{lccc}
\hline Explanation & Test & Test Statistic & Probability Value \\
\hline GMM Instruments for Levels & Hansen & 10.58 & 0.102 \\
Gmm (CF/K, lag (3 4)) & Difference & 12.05 & 0.845 \\
& Hansen & 12 & 0.8 \\
Gmm (S/K, lag (4 4)) & Difference & 10.62 & 0.156 \\
& Hansen & 17.97 & 0.391 \\
Gmm (CLRY, lag (3 4)) & Difference & 4.65 & 0.702 \\
Gmm (סP/P, lag (2 2)c) & Hansen & 18.8 & 0.34 \\
Gifference & Hansen & 3.82 & 0.8 \\
Gmm (CDPR, lag (3 5)) & Difference & 22.54 & 0.488 \\
Instrument Variables (t-10, & Hansen & 0.08 & 0.776 \\
t-11, t-12, t-13, t-14, t-15, & Difference & 16.06 & 0.246 \\
d-US, d-UK, d-JP, d-FR) & Hansen & 6.57 & 0.833 \\
\hline
\end{tabular}

Table A.3.2

Exclusive Hansen Test Results of Variables at Analysis (2)

\begin{tabular}{|c|c|c|c|}
\hline Explanation & Test & Test Statistic & Probability Value \\
\hline \multirow{2}{*}{ GMM Instruments for Levels } & Hansen & 12.14 & 0.206 \\
\hline & Difference & 11.65 & 0.706 \\
\hline \multirow{2}{*}{ Gmm (CDPR, lag ( 1 2 2)) } & Hansen & 12.27 & 0.725 \\
\hline & Difference & 11.52 & 0.174 \\
\hline \multirow{2}{*}{ Gmm (ROE, lag (1 5)c) } & Hansen & 21.13 & 0.39 \\
\hline & Difference & 2.66 & 0.617 \\
\hline \multirow{2}{*}{ Gmm (LR, lag (4 5)c) } & Hansen & 23.54 & 0.316 \\
\hline & Difference & 0.24 & 0.97 \\
\hline \multirow{2}{*}{$\operatorname{Gmm}(\delta \pi / \pi, \operatorname{lag}(23))$} & Hansen & 20.83 & 0.106 \\
\hline & Difference & 2.96 & 0.982 \\
\hline \multirow{2}{*}{ Gmm (סTA/TA, lag (1 4)c) } & Hansen & 21.96 & 0.343 \\
\hline & Difference & 1.83 & 0.767 \\
\hline \multirow{2}{*}{$\operatorname{Gmm}(\delta P / P, \operatorname{lag}(44))$} & Hansen & 20.84 & 0.346 \\
\hline & Difference & 2.94 & 0.709 \\
\hline \multirow{2}{*}{$\begin{array}{l}\text { Instrument Variables (t-10, } \\
\text { t-11, t-12, t-13, t-14, t-15, } \\
\text { d-US, d-UK, d-JP, d-FR) }\end{array}$} & Hansen & 15.56 & 0.623 \\
\hline & Difference & 8.22 & 0.222 \\
\hline
\end{tabular}

